\title{
POLA MAKAN IBU HAMIL YANG MEMPENGARUHI KEJADIAN KEK DI PUSKESMAS GABUS I KABUPATEN PATI
}

\author{
Irfana Tri Wijayanti \\ Sekolah Tinggi IImu Kesehatan Bakti Utama Pati, Jl. Ki Ageng Selo No 15 Pati, 081225066200 \\ Email: irfanawijayanti@gmail.com
}

\begin{abstract}
ABSTRAK
Menurut WHO kejadian kurang gizi pada ibu hamil berkisar 20-48\%. Kurangnya gizi pada ibu hamil dapat dipengaruhi oleh beberapa faktor, salah satunya adalah pola makan. Dari survey awal pada 10 ibu hamil yang KEK di wilayah kerja Puskesmas Gabus I diketahui bahwa terdapat 7 (70\%) responden dengan pola makan buruk sedangkan 3 (30\%) responden dengan pola makan baik. Tujuan penelitian ini, untuk menganalisis hubungan pola makan dengan Kejadian KEK pada ibu hamil di Wilayah Kerja Puskesmas Gabus I Kabupaten Pati.Jenis penelitian menggunakan analitik korelasi dengan metode penelitian survey. Pendekatan waktu cross sectional. Populasi dalam penelitian ini sebanyak 117 di Wilayah Kerja Puskesmas Gabus I Kabupaten Pati. Sampel yang diambil 35 ibu hamil dengan menggunakan stratified random sampling. Uji statistic menggunakan chi square. Hasil penelitian diketahui 18 responden (51,4\%) pola makan cukup, 23 responden $(65,7 \%)$ tidak mengalami Kurang Energi Kronik (KEK). Hasil uji Chi Square diperoleh ( $X^{2}$ hitung $=15,027$ dan pvalue $=$ 0,001) yang berarti Ada hubungan antara pola makan dengan KEK di Wilayah Kerja Puskesmas Gabus I Kabupaten Pati. Saran disampaikan kepada: Kepala Puskesmas Gabus I dapat merencanakan progam penyuluhan maupun pendidikan kesehatan tentang memperbaiki gizi ibu hamil. Pada petugas kesehatan, memberikan pendidikan kesehatan tentang pola makan ibu hamil
\end{abstract}

Kata Kunci : pola makan, kurang energi kronik

\begin{abstract}
According to WHO the incidence of malnutrition in pregnant women ranges from 20-48\%. Lack of nutrition in pregnant women can be influenced by several factors, one of which is diet. From the initial survey of 10 SEZ pregnant women in the Gabus Health Center I, it was found that there were $7(70 \%)$ respondents with poor diet while $3(30 \%)$ respondents had a good diet. The purpose of this study was to analyze the relationship between eating patterns with SEZ events in pregnant women in the Gabus I Health Center Pati District. This type of research used analytic correlation with survey research methods with cross sectional time approach. The population in this study was 117 in the Gabus I Health Center Pati District. Samples were taken 35 pregnant women using stratified random sampling. Test statistics used chi square. The results of the study revealed that 18 respondents (51.4\%) had enough diet, 23 respondents (65.7\%) did not experience Chronic Energy Deficiency $(S E Z)$. Chi Square test results were obtained $\left(X^{2}\right.$ count $=15.027$ and pvalue $\left.=0.001\right)$ which means that there is a relationship between eating patterns with SEZs in the Gabus I Health Center Pati District. Suggestions submitted to: The head of the Gabus I Health Center can plan an extension program and health education about improving nutrition for pregnant women. For health workers, provide health education about the diet of pregnant women
\end{abstract}

Keywords: diet, chronic energy lack 


\section{LATAR BELAKANG}

Kebutuhan energi pada trimester I meningkatkan secara minimal, kemudian sepanjang trimester II dan trimester III kebutuhan energi meningkat sampai akhir kehamilan.Energi tambahan selama trimester II diperlukan untuk pemekaran jaringan ibu seperti penambahan volume darah, pertumbuhan uterus dan payudara serta penumpukan lemak selama trimester III energi tambahan digunakan unntuk pertumbuhan janin dan plasenta (Kristiyanasari, 2010).

Status gizi ibu pada waktu pembuahan dan selama hamil dapat mempengaruhi pertumbuhan janin yang sedang dikandung (Pudjiadi, 2005). Empat masalah gizi utama di Indonesia yaitu Kekurangan Energi Protein (KEP),Gangguan Akibat Kekurangan Yodium (GAKY), Kekurangan Vitamin A (KVA), danAnemia Gizi Besi (AGB). Di Indonesia banyak terjadi kasus KEK (Kekurangan Energi Kronis) terutama yang kemungkinan disebabkan karena adanya ketidak seimbangan asupan gizi (energi dan protein), sehingga zat gizi yang dibutuhkan tubuh tidak tercukupi.Hal tersebut mengakibatkan pertumbuhan tubuh baik fisik ataupun mental tidak sempurna seperti yang seharusnya.lbu hamil yang menderita KEK mempunyai risiko kematian ibu mendadak pada masa perinatal atau risiko melahirkan bayi dengan berat lahir rendah (BBLR). Pada keadaan ini banyak ibu yang meninggal karena perdarahan, sehingga akan meningkatkan angka kematian ibu dan anak (Chinue, 2009).

Menurut WHO (World Health Organization) kejadian kekurangan gizi pada ibu hamil berkisar sekitar antara 20-48\% dengan di temukannya keadaan ibu hamil yang mengalami kekurangan gizi.

Angka kematian ibu (AKI) di jawa tengah selama tahun 2012 mencapai 675 kasus, cenderung meningkat di banding tahun sebelumnya. Pada tahun 2011 jumlah AKI tercatat sebanyak 668 kasus dari 592.000 ibu hamil, sementara sepanjang 2012 jumlah AKI bertambah menjadi 678 kasus dari 604.000 ibu hamil. Berdasarkan SDKI 2012, rata-rata angka kematian ibu (AKI) tercatat mencapai 359 per
100.000 kelahiran hidup. Rata- rata kematian ini jauh melonjak di banding hasil SDKI 2007 yang mencapai 228 per 100.000 .

Menurut Sadjaja (2010) Kurang energi kronik (KEK) adalah suatu keadaan kekurangan makanan dalam waktu yang lama sehingga menyebabkan ukuran indeks masa tubuhnya (IMT) dibawah normal kurang dari 18,5 untuk orang dewasa. Sedangkan menurut Syaifudin (2002) kejadian kekurangan energi kronik pada ibu hamil ukuran lingkar lengan atas (LILA) $<23,5 \mathrm{~cm}$, kenaikan berat badan tidak sesuai dengan umur kehamilan dan indeks masa tubuh (IMT) < 18,5 adalah $30 \%$

Menurut Arisman (2007) faktor-faktor yang mempengaruhi KEK pada ibu hamil adalah keadaan sosial ekonomi ibu yang meliputi pendidikan, pekerjaan, pendapatan, status perkawinan dan jarak kelahiran serta paritas. Menurut Notoatmojo (2003) faktor lain yang mempengaruhi KEK pada ibu hamil adalah Perubahan Pengetahuan, Sikap, perilaku dengan gaya hidup, pola makan serta peningkatan pendapatan mempengaruhi pemilihan jenis dan jumlah makanan yang dikonsumsi.

Berdasarkan survey awal pada 10 ibu hamil yang menderita Kurang Energi Kronik (KEK) di wilayah kerja Puskesmas Gabus I diketahui bahwa terdapat 7 responden (70\%) dengan pola makan buruk sedangkan 3 orang (30\%) dengan pola makan baik. Responden dengan pola makan buruk rata-rata mengatakan bahwa kadang-kadang makan dengan nasi dan sayur saja tanpa menyertakan lauk apalagi dengan buah-buahan. 3 responden mengatakan setiap kali sarapan menggunakan nasi dan bakwan saja yang dibelinya dari warung, terkadang juga dengan mie instan dan 1 responden mengatakan saat sarapan dan makan sore pun sering menggunakan krupuk sebagai lauknya. 2 responden mengatakan tidak mengkonsumsi susu ibu hamil karena baunya amis selain itu tidak suka karena rasanya yang hambar dan ibu tidak mengganti susu dengan sejenisnya seperti keju dan yogurt, 1 responden mengatakan tidak melakukan sarapan tiap pagi hari karena merasa mual setiap kali sarapan. 
Dari latar belakang dan fenomena tersebut diatas maka penulis tertarik untuk melakukan penelitian dengan judul " hubungan pola makan dengan kejadian KEK pada ibu hamil di Wilayah Kerja Puskesmas Gabus I Kabupaten Pati pada tahun 2014.

\section{METODE}

Jenis penelitian yang digunakan dalam penelitian ini adalah analitik korelasi dengan metode penelitian survei. Pendekatan waktu menggunakan cross sectional. Sampel yang diambil 35 ibu hamil dengan menggunakan stratified random sampling. Kriteria sample adalah 1) ibu hamil yang tidak punya penyakit infeksi, 2) ibu hamil yang berumur 20-35 tahun, 3) jarak kehamilan lebih dari 2 tahun, 4) ibu hamil yang parietasnya > 1 . Uji statistic menggunakan chi square. Penelitian dilakukan pada bulan Agustus 2014 s.d Februari 2015 di Puskesmas Gabus I Pati. Instrumen penelitian menggunakan kuesioner.

\section{HASIL}

Hubungan Pola Makan Dengan Kejadian Kurang Energi Kronik Di Wilayah Kerja Puskesmas Gabus I Kabupaten Pati

Tabel 1. Hubungan Pola Makan Dengan

Kejadian Kurang Energi Kronik Di Wilayah

Kerja Puskesmas Gabus I Kabupaten Pati

\begin{tabular}{ccccccc}
\hline \multirow{2}{*}{$\begin{array}{c}\text { Pola } \\
\text { Makan }\end{array}$} & \multicolumn{3}{c}{ Kejadian KEK } & \multicolumn{2}{c}{ Total } \\
\cline { 2 - 6 } & \multicolumn{2}{c}{ KEK } & \multicolumn{2}{c}{ Tidak KEK } & \multicolumn{2}{c}{} \\
\hline Baik & 0 & 0 & $\mathbf{f}$ & $\%$ & $\mathbf{f}$ & $\%$ \\
\hline Cukup & 9 & 25,7 & 9 & 25,7 & 18 & 51,4 \\
\hline Buruk & 3 & 8,6 & 0 & 0 & 3 & 8,6 \\
\hline Total & $\mathbf{1 2}$ & $\mathbf{3 4 , 3}$ & $\mathbf{2 3}$ & $\mathbf{6 5 , 7}$ & $\mathbf{3 5}$ & $\mathbf{1 0 0}$ \\
\hline Sumber
\end{tabular}

Sumber : Data Primer, 2014

Berdasarkan tabel 1 menunjukkan bahwa dari 23 orang $(65,7 \%)$ yang tidak mengalami Kurang Energi Kronik (KEK), memiliki pola makan baik sebanyak 14 orang $(40,0 \%)$, sedangkan 12 orang $(34,3 \%)$ yang mengalami Kurang Energi Kronik (KEK), memiliki pola makan cukup sebanyak 9 orang $(25,7 \%)$.

Hasil uji korelasi Chi Square di peroleh nilai Chi Square15,027 >Chi Square tabel 5,991 dan pvalue $=0,001<0,05$ berarti $\mathrm{Ha}$ diterima. Hal ini dapat disimpulkan bahwa ada hubungan yang signifikan antara pola makan dengan kejadian kurang energi kronik pada ibu hamil di Wilayah Kerja Puskesmas Gabus I Kabupaten Pati.

\section{PEMBAHASAN}

Pola makan yang baik selalu mengacu kepada gizi seimbang yaitu terpenuhinya semua zat gizi sesuai dengan kebutuhan dan seimbang. Sedangkan terdapat enam unsur gizi yang harus dipenuhi yaitu karbohidrat, protein, lemak, vitamin, mineral dan air. Karbohidrat, protein dan lemak merupakan zat gizi makro sebagai sumber energi, sedangkan vitamin dan mineral merupakan zat gizi mikro sebagai pengatur kelancaran metabolisme tubuh (Adriani.Wirjatmadi, 2012).

Pola makan ibu hamil di Wilayah Kerja Puskesmas Gabus I Kecamatan Gabus Kabupaten Pati ada hubungan dengan kejadian Kurang Energi Kronik, Saat dilakukan penelitian di Wilayah Kerja Puskesmas Gabus I Kecamatan Gabus Kabupaten Pati menunjukkan bahwa sebagian besar responden mempunyai pola makan cukup, ini dapat dilihat dari jawaban kuesioner. Sebanyak 35 responden (100\%) berpendapat mencuci bahan makanan sebelum diolah dan 18 orang $(51,4 \%)$ berpendapat bahwa ibu tidak melakukan sarapan setiap pagi hari, sedangkan 17 orang $(48,5 \%)$ ibu hamil mengatakan bahwa selama hamil tidak makan 2 kali lipat dari sebelum hamil (4-5 piring nasi setiap hari).

Perilaku konsumsi makan merupakan salah satu bentuk perilaku pencegahan penyakit yaitu respon untuk melakukan pencegahan penyakit dan upaya mempertahankan serta meningkatkan kesehatannya, seperti dalam rangka pencegahan KEK pada ibu hamil (purwoastuti dan walyani, 2015 dalam penelitian Febriyani). Kebutuhan selama kehamilan berbeda-beda untuk setiap individu dan juga dipengaruhi oleh riwayat kesehatan dan status gizi sebelumnya. Kekurangan asupan pada salah satu zat akan mengakibatkan kebutuhan terhadap sesuatu nutrien terganggu dan kebutuhan nutrisi yang tidak konstan selama kehamilan. 
Sejalan dengan penelitian Rahmaniar (2013) dengan judul faktor-faktor yang berhubungan dengan kekurangan energi kronis pada ibu hamil di Tampa Padang, Kabupaten Mamuju, Sulawesi Barat, diketahui bahwa ada hubungan pola makan dengan kejadian KEK $(P=0,015)$.

Menurut asumsi peneliti, adanya hubungan pola makan dengan kejadian KEK disebabkan ibu yang memiliki pola makan baik akan terpenuhi kebutuhan gizi selama hamil karena mengkonsumsi 2 potong lauk setiap makan, mengkonsumsi vitamin-vitamin selama kehamilan dan mengkonsumsi obat penambah darah. Adanya konsumsi lauk sesuai dengan kebutuhan ibu hamil tersebut menyebabkan kebutuhan zat gizi selama hamil terpenuhi begitu juga ibu mengkonsumsi vitamin dan obat penambah darah selama hamil, maka mereka akan memiliki daya tahan tubuh yang baik dan jarang terkena penyakit sehingga berdampak pada KEK .

Hal ini disebutkan dalam buku Waryana (2010) yang menyatakan bahwa pada wanita hamil membutuhkan lebih banyak zat gizi dari selama hamil maupun sebelum hamil dan pertumbuhan janin tergantung dari penyediaan zat gizi dari ibu hamil.

Kategori Angka Kecukupan Gizi (AKG) ibu hamil berdasarkan permenkes No 75 tahun 2013, kebutuhan energi pada masa kehamilan trimester I, II, III mengalami peningkatan yang signifikan, dimana kebutuhan energi ibu hamil dibutuhkan untuk pertumbuhan janin dan plasenta serta pembentukan enzim dan hormon yang mengatur pertumbuhan janin. Menurut hasil penelitian Gotri, dkk (2016), kalori ini diperlukan ibu untuk dapat berfungsi dengan baik. Ibu hamil yang mengalami KEK selama kehamilan memiliki resiko tinggi melahirkan bayi dan mengalami kerusakan otak dan sum sum tulang karena 2-5 minggu pertama adalah pembentukan sistem saraf dan cenderung akan melahirkan bayi berat badan lahir rendah (BBLR).

Berdasarkan hasil penelitian ini, maka ibu hamil yang pola makannya buruk akan cenderung mengalami kurang energi kronik karena kebutuhan gizi ibu hamil banyak, selain untuk tubuh ibu sendiri juga untuk bayi dikandungannya.

Hasil penelitian ini sesuai dengan penelitian Khifdiyatus Sa'adah (2013) yang menemukan adanya hubungan nutrisi dengan kejadian Kurang Energi Kronik (KEK) pada ibu hamil.

Tindak lanjut yang bisa dilakukan adalah memberikan pendidikan kesehatan tentang pola makan dan kebutuhan gizi ibu hamil dan resiko apabila tidak terpenuhinya kebutuhan gizi ibu hamil bagi ibu dan janin yang di kandungannya.

\section{KESIMPULAN DAN SARAN}

Ada hubungan yang signifikan antara pola makan dengan kejadian kurang energi kronik di Puskesmas Gabus I Pati.

Bagi petugas kesehatan khususnya yang berada di Wilayah Kerja Puskesmas Gabus I, lebih meningkatkan dalam memberikan pendidikan kesehatan tentang pola makan ibu hamil termasuk cara menyusun menu makan dengan bahan-bahan makanan yang mudah didapat supaya kebutuhan gizi ibu hamil terpenuhi. Bagi ibu hamil, menjaga pola makan dan makan makanan yang bergizi supaya gizi selama hamil terpenuhi. Bagi Kepala Puskesmas, dapat menjadi masukan dalam merencanakan progam untuk memberikan penyuluhan maupun pendidikan kesehatan tentang memperbaiki gizi ibu hamil sehingga kejadian KEK pada ibu hamil berkurang. Bagi peneliti selanjutnya, melakukan penelitian dengan variabel lain yang dapat mempengaruhi kejadian kurang energi kronik.

\section{REFERENSI}

Adriani, Merryana.,dkk. 2012. Pengantar Gizi Masyarakat. Jakarta: Kencana Prenada Media Group

Arikunto, Suharsimi. 2013. Prosedur Penelitian. Jakarta: Rineka Cipta

Arisman. 2007. Gizi Dalam Daur Kehidupan. Jakarta : Buku Kedokteran EGC

Baliwati, dkk, editor. 2006. Pengantar Pangan dan gizi. Jakarta: Penebar Swadaya

Budiarto, Eko. 2002. Biostatistik untuk Kedokteran dan Kesehatan 
Masyarakat. Jakarta: Buku Kedokteran EGC

Febriyani. 2017. Faktor-Faktor Yang Berhubungan Dengan Kejadian Kekurangan Energi Kronis Pada Ibu Hamil. Jurnal Human Care e-ISSN: 2528-66510; Volume 2 Nomor 3 Tahun 2017. http://ojs.fdk.ac.id

Gotri, Laksmi, Rony (2016). Hubungan Sosial Ekonomi dan Asupan Zat Gizi Dengan Kejadian Kurang Energi Kronik (KEK) pada ibu hamil di wilayah Puskesmas Sei Jang Kecamatan Bukit Bestari Kota Tanjung Pinang Tahun 2016. Jurnal Kesehatan Masyarakat (ejournal) volume 5, nomor 3 Juli 2017 (ISSN: 2356-3346). http://ejournals1undip.ac.id/index.php/jkm

Harti LB, Kusumastuty I, Hariadi I. 2016. Hubungan Status Gizi dan Pola Makan Terhadap Penambahan Berat Badan Ibu Hamil. Indonesian Journal of Human Nutrition Juni 2016. Vol 3 No 1 Suplemen: 54-62. P-ISSN 2442-6636. E-ISSN 2355-3987. www.ijhn.ub.ac.id

Kristiyanasari, Weni . 2010. Gizi Ibu Hamil. Yogjakarta : Nuha Medika

Muliarini, Prita. 2010. Pola Makan Dan Gaya Hidup Sehat Selama Kehamilan. Yogyakarta: Nuha Medika

Notoatmodjo, Soekidjo. 2010. Metodologi Penelitian Kesehatan. Jakarta: Rineka Cipta

Notoatmodjo, Soekidjo. 2012. Metodologi Penelitian Kesehatan. Jakarta: Rineka Cipta.

Nursalam. 2003. Konsep dan Penerapan Metodologi Penelitian IImu Keperawatan. Jakarta: Salemba Medika.

Proverawati, Atikah.,dkk. 2009. Gizi Untuk Kebidanan. Yogjakarta: Nuha Medika

Purwitasari, Desi ., dkk. 2009. Buku Ajar Gizi dalam Kesehatan Reproduksi. Yogjakarta: Nuha Medika

Purwoastuti, E dan Walyani, ES. 2015. Perilaku Softskill Kesehatan "Panduan Untuk
Tenaga Kesehatan. Yogyakarta Pustaka Buku Press.

Sa'adah, Khifdiyatus. (2013) . Hubungan Nutrisi dengan Kejadian (KEK) Kurang Energi Kronik Pada Ibu Hamil di Desa Purwokerto Kecamatan Tayu Kabupaten Pati.

Sugiyono. 2012. Statistik Untuk Penelitian. Bandung: Alfabeta

Sulistiyoningsih, Hariyani. 2011. Gizi untuk Kesehatan Ibu dan Anak.Yogjakarta : Graha IImu

Supariasa IDN. 2012. Penelitian Status Gizi. Jakarta : EGC 